Article

\title{
Linkages of Electoral Accountability: Empirical Results and Methodological Lessons
}

\section{J. S. Maloy}

Department of Political Science, Oklahoma State University, 700 N. Greenwood, Tulsa, OK 74106, USA;

E-Mail: maloyj@okstate.edu; Tel.:+1-918-594-8466

\section{How to Cite this Article}

Maloy, J. S. (2014). Linkages of Electoral Accountability: Empirical Results and Methodological Lessons. Politics and Governance, 2(2), 13-27.

\section{Copyrights}

(C) 2014 by the author; licensee Cogitatio (Lisbon, Portugal). This article is licensed under a Creative Commons Attribution 4.0 International License (CC BY).

\section{Published by:}

\section{COGITATIO}

www.cogitatiopress.com

\section{About the Journal}

Politics and Governance is an innovative new offering to the world of online publishing in the Political Sciences. An internationally peer-reviewed open access journal, Politics and Governance publishes significant, cutting-edge and multidisciplinary research drawn from all areas of Political Science.

www.cogitatiopress.com/politicsandgovernance

\section{Editors-in-Chief}

Professor Andrej J. Zwitter, Faculty of Law, University of Groningen, The Netherlands

Professor Amelia Hadfield, Department of Psychology, Politics and Sociology, Canterbury Christ Church University, UK

\section{Managing Editor}

Mr. António Vieira, Politics and Governance, Cogitatio Press, Portugal 
Article

\title{
Linkages of Electoral Accountability: Empirical Results and Methodological Lessons
}

\author{
J. S. Maloy \\ Department of Political Science, Oklahoma State University, 700 N. Greenwood, Tulsa, OK 74106, USA; \\ E-Mail: maloyj@okstate.edu; Tel.:+1-918-594-8466
}

Submitted: 16 January 2014 | In Revised Form: 7 May 2014 | Accepted: 9 May 2014 | Published: 10 June 2014

\begin{abstract}
A basic theory of electoral accountability is widely accepted by academic opinion: voters cause politicians to gain or lose office through periodic elections, thereby influencing policy through the threat of electoral sanction. Empirical studies run the gamut from findings of strong support for this theory, to mixed or conditional support, to weak or negative results. When electoral processes are analyzed in terms of two distinct causal linkages within a three-part chain of accountability, however, positive findings are revealed as weaker than they appear while a compelling trend emerges toward findings ranging from conditional to negative in the last two decades. This trend is visible in three topical areas economic voting, political corruption, and ideological congruence-and it holds for both presidential and parliamentary regimes as well as for a variety of electoral systems. The new electoral skepticism's unsettling results and insightful methods may help to improve future research and reform efforts alike.
\end{abstract}

\section{Keywords}

accountability; congruence; corruption; economic voting; elections

\section{Issue}

This article is part of a regular issue of Politics and Governance, edited by Professor Andrej J. Zwitter (University of Groningen, The Netherlands) and Professor Amelia Hadfield (Canterbury Christ Church University, UK).

(C) 2014 by the author; licensee Cogitatio (Lisbon, Portugal). This article is licensed under a Creative Commons Attribution 4.0 International License (CC BY).

\section{Introduction}

Widespread concern about "democratic deficits" in late-modern politics often responds to the power of unelected and unaccountable agents, whether governmental, social, or economic. But what about elected but unaccountable agents? According to a sizeable body of research in political science, such a phenomenon is no Frankenstein of the imagination but rather a normal feature of the democratic landscape. Increasing numbers of empirical studies in the last two decades, as well as theoretical reflections over a considerably longer period, suggest that periodic elections are poor vehicles of democratic accountability. How much truth is there in this suggestion?

A deeply entrenched conventional wisdom, popular and scholarly alike, places an "electoral connection" (see Mayhew, 1974) between citizens and governors at the heart of democracy: the former are supposed to control the latter by rewarding them with electoral victory or punishing them with electoral defeat. On the other hand, the development of what might be called "electoral skepticism" over the last two decades has presented a broad front. Studies in the history of ideas have established that elections were understood in the formative years of republican and constitutional thought as supplanting popular power more than enabling it, and that other, non-electoral procedures of accountability have traditionally been preferred by democrats (Manin, 1997; Maloy, 2008, 2011; McCormick, 2011). Analysis of the empirical realities of modern elections has suggested that the conditions under which they could be interpreted as vehicles of accountability are rarely present, leading to a perceived need to substitute specialized "accountability agencies" (Manin, Przeworski, \& Stokes, 1999, pp. 50-51) or "horizontal accountability" (Schedler, 1999, pp. 23-25).

Recent efforts to assess the state of our knowledge about electoral accountability, however, have overlooked the trend toward electoral skepticism (Carson \& Jenkins, 2011; Pande, 2011; Ashworth, 2012), or else have engaged it in relatively narrow institutional con- 
texts (Maravall, 2010). A cognitive gap seems to separate optimists who ignore the grounds for skepticism and skeptics who take accountability deficits for granted and see little potential contribution from further study. My analysis attempts to bridge this gap by bringing optimistic and skeptical studies into direct engagement. Based on evidence from democracies around the world, including both presidential and parliamentary regimes as well as both pluralitarian and proportional electoral systems, I conclude in favor of electoral skepticism across the board. Elections as we know them cannot provide immunity against serious deficits of democratic accountability, though they might remain socially valuable in other respects.

Section 2 outlines an original conceptual framework for assessing electoral accountability empirically, based on the crucial distinction between two halves of a causal chain: the vote-sanction linkage and the sanction-policy linkage. Section 3 reviews recent empirical studies in three key areas of research: economic voting, political corruption, and ideological congruence. I then address in Section 4 specific problems with common methodological choices in studies of electoral accountability. My concluding section explains how better practices in designing empirical studies and interpreting their results can improve our understanding of where and how far electoral accountability can and does obtain.

\section{Conceptual Structure of Electoral Accountability}

The empirical realities of electoral processes, as of many political phenomena, are baroque, complex, and multidimensional-in a word, messy. Scholarly studies of elections are legion and necessarily reflect the messiness of their subject, frequently framing their findings by using terms like "accountability," "responsiveness," and "representation" in rough-and-ready fashion. Knowing or saying everything there is to know or say is impossible, but imposing conceptual parameters on the field of study can at least enable us to aspire to consistency in and clarity about the terms of analysis.

The basic idea behind electoral accountability is that periodic elections should allow voters to reward and punish politicians for governmental conduct, thereby inducing politicians to engage in anticipatory behavior that is responsive to voters' interests (Manin, Przeworski, \& Stokes, 1999, p. 29). This idea must be distinguished from three related concepts: discursive accountability, intrastate checks, and responsiveness. First, the kind of accountability which is supposed to reflect the special role of elections in a democratic state involves more than discursive exchange or the circulation of information; it also involves sanctions. Elections serve this purpose because they are valued not only as an occasion for public debate ("accountability" in the minimal, etymological sense) but also as a sanctioning mechanism (Mainwaring, 2003, pp. 12-14).
Second, periodic elections are supposed to respect the concept of popular sovereignty by giving power to one set of people, voters, over another, politicians. In formal terms, a hierarchic or "vertical" relation is set up between principal and agent (Moreno, Crisp, \& Shugart, 2003 , p. 80 ), a relation that may overlap with but is nonetheless different from "horizontal" or "intrastate" checks between agencies of government (Kenney, 2003, p. 50; Mainwaring, 2003, pp. 20-22). Third, responsive behavior by governmental agents may be considered the end, and accountability (i.e. vertical sanction) the means, of democratic elections. Electoral accountability is therefore not equivalent to democratic responsiveness but rather is meant to describe institutionalized relations of power that cause responsiveness (Ferejohn, 1999, p. 131).

The distinction between accountability and responsiveness is particularly elusive. Because both are pieces of the broader puzzle of political representation, these two concepts are often tacitly conflated in the design and interpretation of empirical research (e.g. Kassow \& Finocchiaro, 2011, pp. 1019-1023). Yet electoral sanction and responsive government are distinct phenomena, and either one may exist in the absence of the other. Thus voters may actually reward some politicians with electoral victory and punish others with electoral defeat without actually seeing public policy steered in responsive ways, while politicians may actually serve voters' real or imagined interests without their political careers' actually depending on that fact. Indeed some advocates of the "political economy" approach to electoral studies now believe that elected politicians' propensity to deliver responsive policy may be an independent function of their "types" (i.e. responsive or otherwise) rather than of any pressures exerted on them while in office (see Ashworth, 2012). This is called a "selection" (or prospective) model as opposed to a "sanction" (or retrospective) model of electoral control.

It helps to think of electoral accountability, then, as part of a chain of causal processes (cf. Powell, 2004, pp. 97-99) within the larger phenomenon of political representation, revolving around sanction as the distincitve middle term. In a formula, (a) periodic elections are supposed to lead to (b) effective sanctions, which are in turn supposed to lead to (c) responsive government (see Figure 1). The vote-sanction linkage refers to accountability in the narrowest sense, while the sanction-policy linkage (ending in responsiveness) refers to the most significant causal ramification of electoral accountability.

To be sure, it is helpful to avoid conflating the terms "accountability" and "responsiveness," as the metaphor of a chain illustrates. Yet it would be odd to study one half of this causal chain without regard to the other. After all, ordinary citizens have common-sense reasons for caring about policy outcomes and about their votes' ability to affect those outcomes, and political scientists do in fact attempt to study both linkages in 
tandem. As long as we bear in mind that these two distinct but related causal processes (or linkages) may present distinctive challenges for research, we can benefit from a critical review of recent empirical studies that address either or both of these linkages in the chain.

$$
\begin{aligned}
& \text { VOTE - periodic elections are illuminated } \\
& \text { by studies of: voting behavior } \\
& \text { public opinion } \\
& \text { political psychology }
\end{aligned}
$$

SANCTION - effective sanctions are illuminated by studies of: electoral outcomes electoral systems

$$
\begin{array}{r}
\text { POLICY - responsive government is illuminated } \\
\text { by studies of: policy outcomes } \\
\text { official behavior } \\
\text { ideological congruence }
\end{array}
$$

Figure 1. The Causal Chain of Electoral Accountability.

\section{Empirical Tests of Electoral Accountability}

This section will review findings in three major fields of study which typically address core questions of electoral accountability: economic voting, corruption, and congruence. The review is not meant to be comprehensive, since not every study within each field is designed to shed light specifically on the problem of electoral accountability, but it does capture the wide range of accountability results which actually exists in each literature, from positive to mixed to negative. Section 4 will then develop a more systematic analysis of the conceptual and methodological strengths and weaknesses of empirical studies that substantially address electoral accountability through distinctive choices about data (see Tables 1 and 2).

\subsection{Economic Voting}

The literature on economic voting has tended to take the causal chain of electoral accountability whole, purporting to measure not only the vote-sanction linkage but also the sanction-policy linkage. Typically some measure of electoral performance is used as the dependent variable, with various measures of economic performance as independent variables. If good and bad economies lead to good and bad electoral results, respectively, for incumbents or their parties, the quanti- tative analysis is interpreted as confirmation that voters use elections to reward governments for good economic times and to punish them for bad. In turn, elections may then be said to induce all politicians to devote themselves to pursuing the voters' more or less unanimous desire for prosperity.

Before reviewing the empirical findings of this literature, it is important to notice the structure and limitations of the typical research design. While electoral performance is used to measure sanctions in the middle of the causal chain, economic measures are used as proxies at the front and back ends. Good economic indicators are assumed to represent both satisfied voters at the front end and responsive government at the back end, leaving good electoral results for incumbents as the only logical connection in the middle. The possibility that voters may be unhappy in good economic times or happy in bad economic times, or that economic performance may be unrelated to governmental conduct, is not contemplated in the basic research design. More precise studies of public opinion on the front end, and of economic policy-making on the back end, would therefore be needed for a tight causal explanation to emerge from the quantitative results.

Even under the simplistic assumptions of the basic research design, the collective verdict of economicvoting studies has been mixed. Inconsistent early results (see Anderson, 2007, p. 274) led to a pivotal study (Powell \& Whitten, 1993) which attempted to distinguish cases in which economic voting does and does not succeed at holding governments accountable through measures of "clarity of responsibility", a concept designed to capture institutional structures that allow voters to gather good information about the performance of particular governmental actors. In the two decades since, Powell and Whitten's finding that electoral accountability obtains only under certain institutional conditions has been followed by several studies reaching similarly restricted conclusions (Samuels, 2004; Zielinski, Slomczynski, \& Shabad, 2005; Ebeid \& Rodden, 2006; Duch \& Stevenson, 2008; Hellwig \& Samuels, 2008). Conditional findings have also emerged from studies focusing on voter psychology rather than institutions (Gomez \& Wilson, 2006; Singer, 2010; Holbrook, Clouse, \& Weinschenk, 2012).

At the same time, studies claiming to confirm the efficacy of retrospective economic voting (Kelly, 2003; Rudolph, 2003; Bengtsson, 2004; Barreiro, 2007; Gelineau, 2007; Alt, Bueno de Mesquita, \& Rose, 2011) are far from insignificant either in number or in the geographic coverage of their datasets. These must be balanced against studies drawing conclusions of a skeptical character (Maravall, 2010; Alcaniz \& Hellwig, 2011; Hellwig, 2012). Reviews of the literature range from the optimistic (Lewis-Beck \& Stegmaier, 2000) to the pessimistic (Anderson, 2007). The most recent review, covering both institutional and psychological facets of 
the empirical literature, tends toward electoral skepticism with its conclusion that "economic voting does not function as envisioned by advocates of democratic accountability" (Anderson, 2007, p. 271). Where does the balance of good evidence and sound interpretation lie? Both sides deserve a hearing.

One of the earliest examples of electoral skepticism is an ambitious analysis of economic voting in all democracies between 1950 and 1990 (Cheibub \& Przeworski, 1999). Using the survival of a government as the dependent variable, Cheibub and Przeworski found that a wide range of economic variables had no significant effect. Only one variable related to unemployment had a modest positive effect on incumbent governments' likelihood of staying in power. On the whole, what this statistical analysis suggests is that plenty of governments with bad economic records survive while plenty with good records do not. The original "clarity of responsibility" study (Powell \& Whitten, 1993) is then replicated with new and expanded data to determine whether that variable could explain away such unaccountable cases. But the results were not positive even when isolating disciplined parliamentary regimes with high levels of clarity, operationalized by majority control over government and high levels of party unity. In other words, despite the intuition that rational citizens judge politicians on past economic performance, the likelihood that an incumbent government survived a re-election bid did not show up as systematically determined by economic conditions during its tenure.

The key to Cheibub and Przeworski's analysis is twofold: its unusually broad geographic and chronologic scope and its use of the survival of a government in office as the dependent variable (Maravall, 2010, p. 91). Few analyses of economic voting as a process of accountability appear to have used a similar operationalization of the dependent variable (i.e. electoral survival rather than voteshare, vote-choice, or approval rating) since 1999. One uses a similarly large dataset and reports a generally negative accountability result (Maravall, 2010), while another conducts a single-country, single-decade study and reports a conditional result (Zielinski, Slomczynski, \& Shabad, 2005). Of the remaining seventeen studies cited above which have appeared in the same period, two (Samuels, 2004; Barreiro, 2007) explicitly criticize the choice of survival of government as the dependent variable. Since there is a wide variety of measurement options that bear not only on economic voting but also on other types of study yet to be considered, a fuller consideration of the methodological issues must be postponed until Section 4.

Table 1. Illustrative results for electoral accountability by topical area.

\begin{tabular}{llll}
\hline \multirow{2}{*}{ ECONOMIC VOTING } & POSITIVE & MIXED & NEGATIVE \\
& $\begin{array}{l}\text { Rudolph 2003, } \\
\text { Alt et al. 2011 }\end{array}$ & $\begin{array}{l}\text { Bengtsson 2004, } \\
\text { Samuels 2004, } \\
\text { Duch \& Stevenson 2008 }\end{array}$ & $\begin{array}{l}\text { Mellwig 2012 } \\
\text { Heravall 2010, }\end{array}$ \\
CORRUPTION & Ferraz \& Finan 2008 & $\begin{array}{l}\text { Lederman et al. 2005, } \\
\text { Tavits 2007a, Chang et al. 2010 }\end{array}$ & Pereira et al. 2009 \\
CONGRUENCE & Erikson et al. 2002, & Canes-Wrone \& Shotts 2004, & Lee et al. 2004, \\
& Jones 2011 & Tavits 2007b & Gilens 2012 \\
\hline
\end{tabular}

Table 2. Illustrative results for electoral accountability by choice of dependent variable.

\begin{tabular}{|c|c|c|c|}
\hline & POSITIVE & MIXED & NEGATIVE \\
\hline OPINION DATA & $\begin{array}{l}\text { Rudolph 2003, } \\
\text { Ansolabehere \& Jones } 2010\end{array}$ & $\begin{array}{l}\text { Gelineau 2007,* } \\
\text { Singer 2010* }\end{array}$ & Alcaniz \& Hellwig 20 \\
\hline VOTE-CHOICE & $\begin{array}{l}\text { Ansolabehere \& Jones 2010, } \\
\text { Jones } 2011\end{array}$ & $\begin{array}{l}\text { Gomez \& Wilson 2006,* } \\
\text { Gelineau 2007,* } \\
\text { Holbrook et al. } 2012\end{array}$ & \\
\hline VOTE-SHARE & $\begin{array}{l}\text { Barreiro 2007, } \\
\text { Jones } 2010\end{array}$ & $\begin{array}{l}\text { Bengtsson 2004, } \\
\text { Hellwig \& Samuels 2008, } \\
\text { Kassow \& Finocchiaro } 2011\end{array}$ & Hellwig 2012 \\
\hline ELECTORAL SURVIVAL & Ferraz \& Finan 2008 & $\begin{array}{l}\text { Zielinski et al. 2005, } \\
\text { Chang et al. } 2010\end{array}$ & $\begin{array}{l}\text { Pereira et al. 2009, } \\
\text { Maravall } 2010\end{array}$ \\
\hline ANTICIPATORY BEHAVIOR & $\begin{array}{l}\text { Erikson et al. 2002, } \\
\text { Alt et al. } 2011\end{array}$ & $\begin{array}{l}\text { Snyder \& Stromberg 2010, } \\
\text { Ferraz \& Finnan 2011, } \\
\text { Gasper \& Reeves } 2011\end{array}$ & $\begin{array}{l}\text { Lee et al. 2004, } \\
\text { Gilens } 2012\end{array}$ \\
\hline
\end{tabular}

NOTE: For the purposes of Tables 1 and 2, I have relied primarily on authors' own introductory and concluding remarks to characterize their findings about accountability as "positive," "mixed," or "negative." However, in several cases where introductory or concluding remarks suggest a positive finding while remarks within the body of the analysis suggest significant conditions or weaknesses in the results, I have classified that finding as "mixed"; such cases are marked by an asterisk in both tables. 
The most direct challenge to Cheibub and Przeworski's pessimistic conclusions has found a conditional accountability result in a single-country study using a similar dependent variable (Zielinski, Slomczynski, \& Shabad, 2005). Poland's legislative elections feature multi-member districts with open candidate lists. Unlike Cheibub and Przeworski, Zielinski and colleagues focus on purely electoral dynamics and do not include non-electoral losses of office through term limits or cabinet reorganization in their analysis. Over four successive elections in the 1990's, they found that members of a governing coalition with poor economic performance (as measured by rising unemployment) were systematically less likely to win re-election (2005, pp. 380-384). But there is a striking condition attached to this result: electoral accountability was effective only with respect to those politicians who failed to wash their hands of the situation by switching parties before the next election (2005, pp. 385-390). On average, one out of every three incumbents running for re-election did so under a different party label from the previous election (2005, pp. 376-379). Politicians' ability to exploit misleading partisan cues to avoid electoral sanction may be less of a hindrance to accountability in strong-party systems.

The most general problem with economic-voting studies as efforts to confirm electoral accountability empirically is that they are often theoretically hampered by the use of economic proxies both for public opinion on the front end of the causal chain (good times mean happy citizens) and for responsive policy on the back end (good times mean deserving incumbents). This kind of research design is more suggestive than rigorous. Precise, separate analyses of the votesanction and sanction-policy linkages would be necessary to confirm the causal story of accountability and thereby rule out non-economic explanations.

As it happens, the most thorough recent analysis of economic voting (Duch \& Stevenson, 2008) redresses this limitation of the classic research design by directly measuring citizens' economic perceptions rather than letting economic outcomes stand as a proxy for them, promising a more precise picture of the beginning of the causal chain of accountability. The trade-off is that the vote-sanction linkage is the object of study here, with no effort to measure the sanction-policy linkage, making this a limited yet worthwhile perspective on accountability. Results from this multi-national analysis indicate that voters' economic perceptions are more strongly associated with changes in parties' vote-share in "closed" economies than "open" ones. The authors' conclusion is that voters are rational, and that their relative inability to sanction policy-makers in open economies is the fault of complex structures of economic decision-making rather than of elections themselves. This might be read as a qualified defense of electoral accountability, except that the authors themselves explicitly dismiss a sanction model for explaining electoral behavior in favor of a selection model in which voters are uninterested in rewarding or punishing past performance (Duch \& Stevenson, 2008, pp. 10-14, 28).

Even when considered apart from such interpretive ambiguities, Duch and Stevenson's finding of conditional results for the existence of economic voting itself-the word "condition" even appears in the subtitle of the book-must be considered in light of a nearly simultaneous review of the economic-voting literature (Anderson, 2007). One concern there is that partisanship may contaminate voters' economic judgments (Anderson, 2007, 279-281; see also Marsh \& Tilley, 2010); another is that institutional "clarity of responsibility" may prove too formidable a prerequisite for accountability, given voters' informational deficits (Anderson, 2007, 282-285). Thus, the finding of conditional results even when voters are assumed to have perfect information (Duch \& Stevenson, 2008, pp. 227-228) actually bears the logical implication of further restricting the real-world scope of accountability. I will address additional concerns about the choice of vote-share as the dependent variable in Section 4.

Economic performance would seem to hold unique promise as an issue on which voters should have a relatively easy time of gathering information and uniting around stable criteria of judgment. This psychological assumption about economic issues has sometimes been qualified or called into question (Singer, 2010; Alcaniz \& Hellwig, 2011; Holbrook, Clouse, \& Weinschenk, 2012), but few other political issues hold as much promise for yielding to widely shared norms of electoral judgment. Whether economic voting exists is a question that must be decoupled from how it functions-as a vehicle of accountability, or not (see Anderson, 2007, pp. 289-290). Therefore the relative weakness, or strong conditionality, of the empirical results in this area remains a cornerstone of the case for electoral skepticism.

\subsection{Corruption}

Pecuniary malfeasance by governmental agents is similar to economic hardship in its presumed ability to unite voters around common evaluative standards. Despite the possibility that some voters may benefit from corruption, the issue in general does not seem to suffer from complexities of identifying means-ends relationships and assigning responsibility to the extent that issues of economic policy-making do. These intuitions, at any rate, make studies of political corruption enticing to scholars interested in observing how far electoral accountability obtains when cognitive obstacles among voters can be overcome. If they cannot turn thieves out of office, after all, what else could elections be good for?

The standard research design for corruption studies differs from that for economic-voting studies. Instead 
of analyzing electoral outcomes over time as the dependent variable, corruption studies tend to use political institutions (including electoral processes) as independent variables in order to test their influence crosssectionally on corruption-related outcomes (Adsera, Boix, \& Payne, 2003; Kunicova \& Rose-Ackerman, 2005; Lederman, Loayza, \& Soares, 2005; Tavits, 2007a). The consistent finding has been that electoral democracies systematically have lower levels of corruption, and electoral accountability serves as one of the assumed causal mechanisms: voters don't like corruption, and periodic elections enable them to prevent it. More specifically, parliamentary regimes have been found to have systematically less corruption than presidential regimes (Kunicova \& Rose-Ackerman, 2005; Lederman, Loayza, \& Soares, 2005). At the same time, single-seat elections tend to do better than proportional representation, and open-list tends to do better than closed-list proportional representation (Kunicova \& RoseAckerman, 2005). Significant results for press freedom (Lederman, Loayza, \& Soares, 2005) and newspaper circulation (Adsera, Boix, \& Payne, 2003) suggest the importance of good information for reducing corruption. Within European states, certain institutional factors of "clarity of responsibility" (i.e. governments controlled by a single party over a relatively long period of time, with little or no influence over policy by opposition parties) make a significant difference in reducing corruption (Tavits, 2007a).

The central difficulty with such studies is the weakness or absence, sometimes freely admitted (e.g. Kunicova \& Rose-Ackerman, 2005, p. 598), of a causal story to explain the statistical results. It is a challenge to disentangle the myriad of institutions (e.g. federalism) which may influence corruption-related outcomes. The fact that corruption seems to exist in inverse proportion to the degree of the "personal vote," falling from closed lists to open lists to single-member districts, is suggestive of the "electoral connection" between constituents and uniquely identifiable representatives. On the other hand, no significant effect on corruption has been found with the imposition of term limits, which render some incumbents ineligible to run for re-election and thereby preclude the personal vote (Lederman, Loayza, \& Soares, 2005).

The bearing of corruption studies on electoral accountability must remain highly speculative unless electoral outcomes can be factored into the middle of the causal story, as economic-voting studies sometimes do. A few corruption studies have in fact taken this approach. An analysis of corruption trials in Italy and their effects on re-election bids, for example, has found that charges of corruption against incumbents made them less likely to win (Chang, Golden, \& Hill, 2010). But this result has been interpreted by its authors as dependent on the "massive and thorough" media blitz that happened to accompany corruption scandals in Italy in the early 1990's (2010, pp. 215-216). In short, unusual circumstances of intense exposure seem to have been necessary to activate the accountability function of elections.

A similar approach has been taken with mayoral elections in Brazil, where a nationwide system of fiscal audits of municipal governments was introduced in the early 2000's. Analysis of the actual re-election rates of incumbent mayors has showed that, compared to an average rate of $40 \%$, the re-election chances of mayors who were charged with no violations rose to over $50 \%$ while those with three or more violations were only about half as successful (Ferraz \& Finan, 2008).

Since actual re-election is used as the dependent variable, with findings of corruption as an independent variable, the conceptual structure of this research design is similar to that of many economic-voting studies, at least for the vote-sanction linkage. Outcomes variables are used as a proxy for public opinion, and the main item of analysis is whether elections actually apportion rewards and sanctions to incumbents according to voters' presumed will. Since the Brazilian audits were only announced in 2003, and the selection of targets was random, there was probably not enough notice to justify testing responsiveness via anticipatory behavior by incumbents. In an effort to address the sanction-policy linkage, however, the same authors have found that in an earlier period re-eligible mayors were guilty of $27 \%$ less corruption than term-limited mayors in cities lacking locally based media (radio and newspapers) or active public prosecutors (Ferraz \& Finan, 2011). There was no significant difference between re-eligible and ineligible mayors in cities enjoying these informational advantages or, rather puzzlingly, in those lacking a competitive political environment. Taken together, the two studies by Ferraz and Finan seem to complete the causal chain of electoral accountability, from votes to sanctions to responsiveness. Some exponents of the "political economy" approach to electoral accountability have sanguinely cited these results as confirmation that repeated elections can be vehicles of democratic accountability if only the central problem of voter information can be overcome (Pande, 2011, pp. 227, 234; Ashworth, 2012, p. 195).

One problem with the Brazilian-audit studies, however, is familiar from the economic-voting literature: using variables for policy outcomes as a proxy for public opinion is inferior, in terms of causal-explanatory power, to studying the vote-sanction linkage more directly. The importance of assessing Brazilian voters' attitudes toward municipal corruption is heightened by the fact (unnoticed by some reviewers) that a replication of the earlier of the two Brazilian studies has found contrary results. When the vote-sanction linkage was examined on the basis of a different portion of the vast audit data, incumbent mayors charged with fiscal improprieties appeared systematically more likely both to run for re-election and to win (Pereira, Melo, \& 
Figueiredo, 2009). The replication data differed in several respects: it came from audits of all cities in a single state rather than a random sample from around the country; was based on comprehensive audits of municipal budgets rather than partial audits of municipal spending of federal funds only; and was analyzed with control variables for campaign spending, pork-barrel projects (as distinct from illegal expenses), and partisan affiliation (2009, p. 742). These technical discrepancies do not obviously favor one or the other study, on the whole. Thus the possibility that some combination of politicians' skills and voters' preferences may have defied the expectations of rational-choice theory calls for more focussed analysis.

Even if we ignore the negative accountability findings of the Brazilian replication, the Italian study offers a skeptical hint about how to interpret the results of the original Brazilian study in terms of the broader empirical regularities of democratic elections. Chang and colleagues' quantitative results are broadly similar to Ferraz and Finan's: incumbents suspected of corruption are significantly but not overwhelmingly less likely (slightly under $10 \%$ in Italy, somewhat over $10 \%$ in Brazil) to win re-election. Yet the Italian study's conclusion is that the informational circumstances leading to a statistically significant finding of electoral sanction were exceptional and rare (Chang, Golden, \& Hill, 2010, p. 216: "if our interpretation is correct, it does not bode well for political accountability in established democracies"), whereas the Brazilian study's conclusion is more categorical, theoretical, and optimistic (Ferraz \& Finan, 2008, p. 706: "our paper lends strong support to the value of information and the importance of local media in promoting political accountability").

Is there something magical about the $10 \%$ threshold (in likelihood of re-election) crossed by the Brazilian study? More likely, both interpretations are correct at the same time: a modest measure of electoral accountability is possible under conditions of exceptionally good information. If evidence like this is considered "strong support" for the principal-agent theory of electoral accountability (Ashworth, 2012, p. 198), the reason may be that this theory already predicts a highly restricted range of circumstances under which accountability could in principle obtain in the real world. The most thorough of recent explorations of the principalagent perspective on electoral accountability concludes, in conspicuously diplomatic fashion, that "it is less than clear whether the weight attached to the importance of elections in modern representative democracies would emerge from this approach" (Besley, 2006, p. 99).

\subsection{Congruence}

Studies of economic voting and political corruption typically aspire to cover the entire length of the chain of electoral accountability by focusing on issue areas in which outcomes variables can simultaneously serve as proxies for public opinion, by dint of the presumption of voters' homogeneous orientations toward those outcomes. In other issue areas, scholars have attempted to establish correlations between public opinion and policy outcomes through more precise and subtle measures of responsiveness, or "congruence" with voters. These measures typically involve comparing constituents' survey responses with representatives' behavior on various policy domains after both are aggregated on a common ideological (usually left-right) scale.

A great deal of research of this kind has been conducted in American politics, often with very positive conclusions about representatives' congruence (e.g. Erikson, Mackuen, \& Stimson, 2002). Yet there is considerable disagreement about the basic relationship between voters and policies, even before we reach the causal question about electoral sanctions in between. On one hand, several recent studies have reported positive results for electoral accountability by demonstrating congruence under circumstances favorable to imputing periodic elections as a cause. Historical studies of the U.S. Senate have found that senators became more closely aligned with ordinary voters after direct popular elections replaced selection by state legislatures (Meinke, 2008; Gailmard \& Jenkins, 2009), using a broad-gauged conception of congruence which spans multiple issue areas. A narrower study of U.S. presidents' budget policies has found them to become systematically congruent with public opinion under two conditions: the president must be in the last two years of his first term and must have approval ratings that are neither unusually high nor unusually low (CanesWrone \& Shotts, 2004). Data collected outside the U.S. have shown varying but appreciable levels of left-right congruence, more convincingly in the long run than when seen election by election (McDonald, Mendes, \& Budge, 2004; Budge, Keman, McDonald, \& Pennings, 2012), as well as reciprocal responsiveness between public policy and public opinion on highly salient fiscal issues (Wlezien \& Soroka, 2012).

Elsewhere within the congruence literature, some studies have turned up more limited or partial forms of congruence and have harbored doubts about the presumed efficacy of electoral processes as causative of ideological or policy outcomes. A recent analysis of American national politics, disaggregated into several different policy areas, has found little systematic congruence with the vast majority of citizens who do not belong to economic or interest-group elites (Gilens, 2012, pp. 70-123). Another recent assessment found only "mixed evidence" for the linkage between electoral sanctions and responsive policy in the American context (Grimmer, 2013, p. 624). Comparative research on responsiveness could also explore this causal issue directly. 
Some elections scholars have responded to these mixed results by scaling back the causal-interpretive ambitions of their studies, retreating from the sanction-policy linkage and isolating the vote-sanction linkage. One study of this type has found that congruence between voters' policy preferences and their perceptions of candidates' policy preferences bears a stronger systematic relation to individual vote-choice than do actual policy outcomes (Jones, 2011). For politicians, position-taking is more important to re-election than actual policy (2011, pp. 779-780). If voters are not getting the kind of responsive policy that the theory of electoral accountability (at its most ambitious) aspires to, they at least believe themselves to be rewarding politicians for similar preferences and punishing them for discrepant preferences (Ansolabehere \& Jones, 2010, p. 589). As we will see below (in Section 4), this kind of analysis must be evaluated in terms of the suitability of its variables for capturing the vote-sanction linkage.

Congruence studies face a number of challenges as contributions to research on electoral accountability. Despite their generally positive quantitative results in studies of the United States, there is still a problem of causal relevance: congruence may have non-electoral causes, after all. For instance, politicians may be inducing voters to become congruent rather than vice versa (Jacobs \& Shapiro, 2000, pp. 44-70), as even electorally optimistic studies recognize (Ansolabehere \& Jones, 2010, p. 593). A related problem is the empirical reality of widespread voter ignorance about public affairs, even in relatively affluent and educated societies (Hardin, 2000). An important methodological lesson immediately follows from this fact: researchers investigating congruence between voters and politicians (e.g. Ansolabehere \& Jones, 2010; Jones, 2011) should avoid using opinion data from opt-in surveys, which tend to have a selection bias toward better informed members of society. A further methodological problem is that a focus on roll-call position-taking (e.g. Bovitz \& Carson, 2006; Gailmard \& Jenkins, 2009) can make it difficult to detect the influence of special interests on policy between one election and the next, since many important policy benefits are actually distributed in less visible ways, such as legislative amendments and regulatory directives (Fellowes \& Wolf, 2004).

Congruence studies can be an important adjunct to studies of electoral accountability in the narrow sense, since the former tend to investigate the responsiveness of policy at the end of the chain of representation. But optimistic results for that end of the chain can reveal little about the rest of the chain in the absence of additional study or careful causal analysis.

\section{Conceptual and Measurement Issues}

Part of the difficulty in evaluating empirical tests of electoral accountability lies in the variety of operation- al schemes used to measure the dependent variable. Among the numerous studies that have appeared to vindicate electoral accountability, relatively few have directly challenged the most skeptical economic-voting studies (Cheibub \& Przeworski, 1999; Maravall, 2010) by using measures similar to electoral survival. Scholars of electoral accountability must be careful to distinguish the stronger from the weaker operational methods, and above all to ensure that interpretations of their results bear a reasonable relation to the conceptual rationale behind their variables of choice. I will now review, in ascending order of plausibility, the main options for operationalizing the dependent variable.

\subsection{Approval Ratings and Vote-Choice}

The least plausible option in empirical analyses of electoral accountability is to use approval ratings of parties or politicians as the dependent variable. Numerous studies of public opinion appear to rest on the assumption that studying the background conditions of voter psychology is as good as studying the entire causal chain of electoral accountability. Their implicit logic is that, if public opinion can be shown to vary in rational and expected ways with changes in certain policies or policy outcomes, that systematic relation is proof of accountability. Of course this logic is incomplete without further empirical investigation of the vote-sanction linkage between public opinion and electoral outcomes. Despite the fact that this methodological problem has long been recognized (see Lewis-Beck \& Stegmaier, 2000, p. 188; Powell, 2004, p. 103), studies continue to be published purporting to test the existence of electoral accountability by way of approval ratings (Kelly, 2003; Rudolph, 2003; Singer, 2010). The value of such analyses hinges on their role of illuminating a single node (i.e. voter psychology) of a single linkage in the chain of accountability (e.g. Alcaniz \& Hellwig, 2011; Holbrook, Clouse, \& Weinschenk, 2012).

A similar caution applies to other types of data from opinion surveys, such as self-reported voting. Votechoice at the individual level is better than approval ratings because it at least takes a step toward electoral behavior, and several studies have used this as the dependent variable in order to test the existence of electoral accountability (Gomez \& Wilson, 2006; Gelineau, 2007; Ansolabehere \& Jones, 2010; Jones, 2011). But the well-known perils of relying on voters' self-reported behavior (see Burden, 2000) leave considerable room for error. Data collected before an election about whom an individual voter plans to support seem little better than approval ratings, and data collected after an election about whom an individual reportedly supported are subject to bias and rationalization. Scholars have been at loggerheads over which form of reported vote-choice, ex ante or ex post, is less bad (see Gomez \& Wilson, 2007, p. 57; Godbout \& Belanger, 2007). Yet 
some consensus may be possible: both should be equally avoided when the vote-sanction linkage is at issue.

\subsection{Vote-Share}

A more justifiable approach is to use changes in the share of votes earned by a party or candidate from one election to the next as the dependent variable. As long as a given election can be verified as free from error and fraud, voting tallies have better validity as a measure of electoral behavior than reported vote-choice. Numerous studies investigating electoral accountability have used vote-share as the dependent variable (e.g. Bengtsson, 2004; Samuels, 2004; Ebeid \& Rodden, 2006; Barreiro, 2007; Jones, 2010; Hellwig, 2012; see also Pande, 2011, pp. 227-228), including the most notable book-length treatment of economic voting in recent years (Duch \& Stevenson, 2008), and this practice has been called the "standard approach" (Hobolt \& Hoyland, 2011, p. 488) to operationalizing electoral accountability. Yet scholars rarely consider the validity of vote-share data, and the paucity of mechanisms for verifying electoral processes (and the voting tallies to which they give rise) is a critical defect for not only political but also scholarly practice.

Even if we could always verify the accuracy of electoral results, the use of vote-share data would still force a conceptual mismatch onto electoral accountability. The problem, simply, is that losing votes is necessary but not sufficient for electoral failure (or not even necessary, for coalition governments in parliamentary systems). If the economy is bad, for instance, even an incumbent politician's grandmother could predict that some voters will desert her favored candidate (hence the insistence that political scientists strive to pass "the grandmother test"; see Shapiro, 2005, ch. 2). The relevant questions for politicians are, how many deserters are likely and how might they be off-set? The answers may vary considerably according to circumstances, as college instructors who are subject to course evaluations by students are aware. We can guess which policies or actions in the classroom may produce a noticeable increase or decrease in evaluation scores at the end of the semester, yet we do not necessarily act as though any incremental change amounts to an effective sanction-it depends on our departments' or universities' particular institutions and personalities. By a similar logic, researchers are not entitled to infer the existence of electoral accountability from vote-share analysis alone. What matters is the sanction, which comes from actual electoral victory or defeat. After all, the selective pressures of competitive elections place a premium on deft and less than risk-averse politicians who can convert a hemorrhaging of votes due to bad policy outcomes into an electorally inconsequential trickle (Maravall, 1999, pp. 172-191).
It is emblematic of what is at stake in the choice of dependent variable that a less pessimistic account of electoral accountability than the analysis of Cheibub and Przeworski (1999), but appearing in the same edited collection, opts for vote-share (Stokes, 1999). This study of Latin American presidential elections from 1982 to 1995 found that incumbents who flagrantly betrayed major campaign pledges could compensate expected losses through good economic performance. In one sense, it should be good news for electoral accountability that presidents who switched to their opponents' economic policies normally cost their party around $9 \%$ of vote-share at the next election, or that good economic results from such switches normally reversed that loss and produced a more than $2 \%$ gain in vote-share $(1999,115-116)$. But the very fact that politicians can neutralize one voting bloc with another, through policy outcomes over which they may or may not have control, illustrates the general principle that vote-share analysis cannot capture the existence of an effective sanction. Politicians operate in specific contexts with an eye toward ultimate victory or defeat, and that dichotomous result is where any sanction must come from.

\subsection{Electoral Survival}

The next step, then, would be to use actual re-election or loss of office as the dependent variable. This is related to the concept of "survival in office" or, in timeseries analysis, "hazard rate" (Cheibub \& Przeworski, 1999). Only a few studies have taken this methodological option, and most of them have sounded a pessimistic note about electoral accountability. On the subject of economic voting, the most recent example of a longrange, cross-national study has found that several economic variables are related to survival in office either weakly or not at all (Maravall, 2010), while a singledecade, single-country study has found that members of an incumbent governing coalition were less likely to win re-election during hard times unless they switched parties before the election (Zielinski, Slomczynski, \& Shabad, 2005). On the subject of political corruption, a single-election study of Brazilian mayors has found a modest level of accountability by using electoral survival as the dependent variable (Ferraz \& Finan, 2008), though these results have been disputed (Pereira, Melo, \& Figueiredo, 2009), while a long-range study of Italian parliamentary elections has found significant results with similar measures only during two years of unusually intensive media coverage of corruption (Chang, Golden, \& Hill, 2010). All in all, the use of actual re-election as the dependent variable has been rather rare and has tended toward the conclusion that periodic elections are weak or exceptional as political mechanisms of reward and punishment.

The logic behind using survival in office as the de- 
pendent variable, that the actual loss of power is what motivates incumbent representatives and parties to govern responsively, has been directly challenged. The twofold criticism includes (a) the observation that using incremental changes in vote-share is more apt to show significant results in statistical analysis, coupled with (b) the assertion that politicians should be responsive to vote-share regardless of electoral outcomes (Samuels, 2004, pp. 425-426). The first point carries the implication that variables are to be chosen according to their propensity to yield statistically significant coefficients rather than conceptually coherent interpretations thereof. The second point only begs the underlying conceptual question about how the electoral sanction is supposed to work on politicians.

There is scope, nonetheless, for legitimate criticism of survival in office as a measure of electoral accountability. For one thing, the expiration of a coalition government in a parliamentary system is often not a result of electoral processes, as in cases where elected representatives reshuffle a cabinet or form a new governing coalition (Maravall, 2010, pp. 82-83). Though the next elections would seem likely to figure in the calculations of the key players, the linking proposition necessary to the logic of accountability - that elite machinations in coalition formation are systematically responsive to anticipated voter behavior-would require separate analysis to establish the relevance of survival in office to the theory of electoral accountability in such cases. Empirical data so far suggest that partisan elites' motives for making or unmaking governments are not closely aligned with voters' (2010, pp. 93-98). Using survival in office as the dependent variable may sensitize us to the important fact that loss of office may happen through non-electoral means, but for that very reason this operational technique offers limited purchase on the workings of elections themselves. Electoral survival, narrowly speaking, is therefore preferable.

A second problem involves term limits, which may function to limit electoral accountability in presidential regimes (or in single-seat elections generally) in a manner similar to party-elite machinations in parliamentary regimes (or in multi-seat elections). Indeed Cheibub and Przeworski (1999) acknowledged that their negative findings for economic voting may be in part explained by the fact that term-limited presidents may lose office despite excellent economic conditions and widespread voter approval. The classic theoretic argument is that any incumbent who is not running for reelection cannot in principle be motivated by sanctions at the hands of voters (Manin, Przeworski, \& Stokes, 1999, p. 34n; Fearon, 1999, pp. 61-62). This logic about term limits is analytically straightforward; the empirical evidence is less robust, though generally supportive (Canes-Wrone \& Shotts, 2004; Gelineau, 2007). Yet it is possible for voters to hold incumbent parties responsible for the conduct of individually term-limited mem- bers of government who care about their party's future prospects (Samuels, 2004, pp. 426, 429-430). In singleseat elections, then, term limits should not be considered a reason to dispense with survival in office as a measure of electoral accountability without first considering the effects of partisan succession.

Finally, the use of a dichotomous variable like electoral survival presents certain difficulties for statistical analysis which might be ameliorated by substituting continuous data such as vote-share. Yet technical considerations must be subordinate to the conceptual cogency of operational choices with respect to the research question at hand, not the other way around. While vote-share data may be useful for a variety of electoral studies, they fall short of capturing the logic of sanction which lies at the heart of studies of accountability. Thus survival in office is a better measure of accountability in terms of conceptual fit than approval ratings, reports of individual vote-choice, and changes in vote-share. If construed narrowly to mean success or failure at re-election, to the exclusion of inter-electoral shuffling among party leaders, electoral survival is better still.

\subsection{Anticipatory Behavior}

A key limitation remains for studies using electoral survival as the dependent variable: it covers the votesanction linkage but not the sanction-policy linkage. To cover the second half of the causal chain, which requires that elections induce responsiveness in representatives, we must find ways to measure anticipatory behavior by elected officers which would be hard to explain in the absence of an effective institutionalized sanction.

A number of studies have taken this sort of approach to electoral accountability, but there is an important distinction to be made between representatives' behavior and policy outcomes. The classic research design of economic-voting studies, for instance, takes economic outcomes as proxies for responsive behavior. Given the danger that policy outcomes may have little to do with the actions of elected officers, this is an unsafe conceptual bet. Thus studies that focus on measuring policy outcomes, only in the service of a tacit attribution of responsiveness as the causal mechanism behind them (e.g. Alt, Bueno de Mesquita, \& Rose, 2011), are not in fact shedding much light on the process of electoral accountability. At the same time, there is conceptual danger at the other extreme of measuring representatives' behavior independently of outcomes. It is well known that position-taking can be a good strategy for concealing actual policy-making from imperfectly informed voters (Arnold, 1990, pp. 119-120). In studies of legislative representation, for instance, analyzing roll-call voting (Meinke, 2008; Jones, 2011) can be a fool's errand if actual policies and 
policy outcomes are being shaped elsewhere. Representatives may even work behind the scenes to subvert policies that their roll-call records show support for, or to promote policies that their roll-call records show opposition to (Hussey \& Zaller, 2011, p. 337). Positiontaking, then, may be proof of elected officers' belief in the power of publicity more than of their electorally enforced responsiveness-surely not a useless result, but one that falls well short of establishing the empirical existence of accountability.

Researchers must therefore try to steer a middle course between representatives' conduct and policy outcomes when analyzing the sanction-policy linkage. A recent example is provided by a study of the effects of variations in newspaper readership across districts of the U.S. House of Representatives which examined a range of official behaviors, the policy outcome of federal dollars spent within each district, and variables relating to public opinion (Snyder \& Stromberg, 2010). This analysis has found that districts with lower newspaper readership have systematically less knowledgeable constituents, less active and independent representatives, and lower federal spending within the district. In short, the effect of political information on the front end of public opinion and the back end of responsive policy is thoroughly covered, leaving only a closer study of the assumed causal mechanism of the electoral sanction to be examined in the middle of the chain.

Research on disaster relief is another promising avenue for studying responsive government, for several reasons. Like promoting prosperity and reducing corruption, ameliorating the effects of natural disasters can serve as a fairly reliable proxy for public opinion: almost everyone likes it, barring principled libertarians or anarchists. Moreover, by operationalizing responsive policy as moneys spent, the interpretive traps of position-taking and of autonomous or unintended policy outcomes may be avoided. One study of this kind among regional governments in India has found that disaster relief is systematically boosted by voter turnout, partisan electoral competition, and newspaper readership (Besley \& Burgess, 2002). A study of American states has found that the generally negative effects (on vote-share) of natural disasters for incumbents can be compensated by gains for U.S. presidents and state governors who launch or support conspicuous relief efforts (Gasper \& Reeves, 2011). Again, all that is missing from such studies is careful analysis of the electoral sanction itself (for instance, by abandoning vote-share as the dependent variable) to ensure that the intervening causal mechanism between public opinion and responsive policy is actually completing the chain.

Another strategy for measuring responsive behavior, with similar difficulties in specifying electoral sanctions as a causal mechanism, uses indicators of ideological or policy congruence between constituents and representatives. As we have seen above, there is disa- greement in the American context over the causal relation between voters and policies, and one study found "little evidence that members of the U.S. House alter their positions" for the sake of "the probability of winning election" (Lee, Moretti, \& Butler, 2004, p. 848). An aspect of the question which seems well settled, however, involves variation in responsiveness in different phases of the electoral cycle. In other words, responsiveness kicks in when an elected officer is anticipating a close contest for re-election in the near future. The eleventh-hour nature of responsiveness is long established and amply documented. A study of elected judges in American states has found a similar end-of-term effect (Huber \& Gordon, 2004) in which harsher sentences for convicted criminals are handed down, presumably in the expectation that American voters will reward such conduct if they can remember it on election day. As the disaster-relief study has noted, voters are generally inattentive except in the run-up to an election (Gasper \& Reeves, 2011). Difficulty of recall leads voters to weight recent information much more heavily than information about earlier periods of a representative's term (Huber, Hill, \& Lenz, 2012), which may explain why politicians often wait until just prior to election day to engage in deviant behavior resembling responsiveness (Jacobs \& Shapiro, 2000, pp. 43-44).

The end-of-term effect authorizes a strong presumption that representatives are behaving responsively because of the imminent possibility of electoral sanction, since it would be difficult to explain in the absence of such a sanction. Yet studies of last-minute responsiveness also imply that the sanction is less than fully operative most of the time, supporting the theory of electoral accountability only with the addition of a significant proviso: "just before election day." If "only the threat of imminent elections produces a temporary rise in responsiveness to public opinion" (Jacobs \& Shapiro, 2000, p. xviii), responsiveness is abnormal. This empirical regularity suggests that electoral accountability requires terms of office short enough to keep voters constantly on the watch. This consideration does not invalidate the empirical results of the eleventh-hour studies, but it does qualify how we interpret those results in terms of electoral accountability as an empirical phenomenon.

Analysis of anticipatory behavior is the best bet for investigating the sanction-policy linkage, but researchers must not forget the sanctioning node of the linkage and the need for causal analysis to make the chain hold. Responsiveness, at least under American conditions, has been found to be deviant and temporary. This fact seems to reflect the importance of statecraft, of the ability of politicians to control rather than be controlled. Elections are a key part of the institutional environment and therefore an important tool in politicians' quest for control. 


\section{Conclusions}

How well do periodic elections perform as vehicles of democratic accountability? Based on my analysis of key empirical literatures in political science in the last couple of decades, set within a precise conceptual framework that distinguishes two sections of the causal chain of accountability, the answer to this important question is rather pessimistic. The most rigorous methods have tended to yield more skeptical results in recent years (see Table 2). Elections perform a variety of functions in modern constitutional republics, but their accountability anemia means that they cannot be a solution to "democratic deficits" in such republics without major alterations in institutional forms or practical circumstances. Though institutional variations have been theorized to make a large difference in electoral accountability (e.g. Powell, 2000), the skeptical trend in empirical studies reviewed above encompasses both presidential and parliamentary regimes as well as both pluralitarian and proportional electoral systems, making this key theoretic issue ripe for further study.

My conclusions are difficult to square with some powerful and long-standing assumptions in political research. The "electoral connection" (see Mayhew, 1974) between voters and politicians is a stock idea of both popular and scholarly discourse. It often serves as an implicit, untested assumption in constructing causal stories about, for example, why democratic states rarely go to war with one another (e.g. Bueno de Mesquita, Morrow, Siverson, \& Smith, 1999), tend to exhibit relatively low levels of political corruption (e.g. Lederman, Loayza, \& Soares, 2005), or yield any of a variety of other positive policy outcomes (e.g. Alt, Bueno de Mesquita, \& Rose, 2011). Scholarly efforts at improving or "deepening" democracy usually revolve around electoral institutions (e.g. Gerken, 2009). Even attempts to reconceive democratic accountability in explicitly nonelectoral terms continue to pay homage to the conventional wisdom that repeated elections remain, nonetheless, accountability's primary vehicle (e.g. Grant \& Keohane, 2005, p. 41; Rubenstein, 2007, pp. 618-619). All these branches of political research could profit from a greater sense of realism about what elections have achieved in terms of popular control or democratic power. One normative implication is that nonelectoral options for empowering ordinary citizens visa-vis political elites (see Maloy, 2008; McCormick, 2011) should be high on the menu of institutionaldesign responses to democratic deficits.

Progress in empirical analysis may depend on heeding two key lessons. First, we should observe the key distinction between the vote-sanction linkage and the sanction-policy linkage in pursuit of the kind of plausible causal explanations to which political research naturally aspires. This distinction helps to clarify the contributions of narrow-gauged studies of voter psycholo- gy and policy outcomes within the scholarly division of labor, since they illuminate the far ends of the causal chain of accountability, while accentuating the importance of more direct analysis of two kinds of causal process in the middle regions of the chain. Second, we should avoid operationalizing electoral accountability as a dependent variable in terms of approval ratings, individual vote-choice, or changes in vote-sharethough such variables may be useful in other types of research design, or in studies that are ancillary to electoral accountability. When considering the votesanction linkage we should favor actual electoral survival, and for the sanction-policy linkage we should emphasize anticipatory behavior. It may be that the forces that weaken or sever these linkages are not, on further inspection, as daunting as the scholarly trend of electoral skepticism suggests. But only a concerted effort to match an explicit conceptual framework with precise operational techniques could in principle contribute to the progress of knowledge on these topics.

\section{References}

Adsera, A., Boix, C., \& Payne, M. (2003). Are you being served? Political accountability and quality of government. Journal of Law, Economics, and Organization, 19, 445-490.

Alcaniz, I., \& Hellwig, T. (2011). Who's to blame? The distribution of responsibility in developing democracies. British Journal of Political Science, 41, 389-411.

Alt, J., Bueno de Mesquita, E., \& Rose, S. (2011). Disentangling accountability and competence in elections: Evidence from U.S. term limits. Journal of Politics, 73, 171-186.

Anderson, C. J. (2007). The end of economic voting? Contingency dilemmas and the limits of accountability. Annual Review of Political Science, 10, 271-296.

Ansolabehere, S., \& Snyder, J. M. (2008). The end of inequality: 'One person, one vote' and the transformation of American politics. New York: Norton.

Arnold, R. D. (1990). The logic of congressional action. New Haven: Yale University Press.

Ashworth, S. (2012). Electoral accountability: Recent theoretical and empirical work. Annual Review of Political Science, 15, 183-201.

Barreiro, B. (2007). Explaining the electoral performance of incumbents in democracies. In J. M. Maravall \& I. Sanchez-Cuenca (Eds.), Controlling governments: Voters, institutions, and accountability (pp. 17-44). New York: Cambridge University Press.

Bengtsson, A. (2004). Economic voting: The effect of political context, volatility, and turnout on voters' assignment of responsibility. European Journal of Political Research, 43, 749-767.

Besley, T. (2006). Principled agents? The political economy of good government. New York: Oxford University Press. 
Besley, T., \& Burgess, R. (2002). The political economy of government responsiveness: Theory and evidence from India. Quarterly Journal of Economics, $117,1415-1452$.

Bovitz, G. L., \& Carson, J. L. (2006). Position-taking and electoral accountability in the U.S. House of Representatives. Political Research Quarterly, 59, 297-312.

Budge, I., Keman, H., McDonald, M. D., \& Pennings, P. (2012). Organizing democratic choice: Party representation over time. Oxford: Oxford University Press.

Bueno de Mesquita, B., Morrow, J. D., Siverson, R. M., \& Smith, A. (1999). An institutional explanation of the democratic peace. American Political Science Review, 93, 791-807.

Burden, B. C. (2000). Voter turnout and the National Election Study. Political Analysis, 8, 389-398.

Canes-Wrone, B., \& Shotts, K. W. (2004). The conditional nature of presidential responsiveness to public opinion. American Journal of Political Science, 48, 690-706.

Carson, J. L., \& Jenkins, J. A. (2011). Examining the electoral connection across time. Annual Review of Political Science, 14, 25-46.

Chang, E. C. C., Golden, M. A., \& Hill, S. J. (2010). Legislative malfeasance and political accountability. World Politics, 62, 177-220.

Cheibub, J. A., \& Przeworski, A. (1999). Democracy, elections, and accountability for outcomes. In A. Przeworski, S. C. Stokes \& B. Manin (Eds.), Democracy, accountability, and representation (pp. 222249). New York: Cambridge University Press.

Duch, R. M., \& Stevenson, R. T. (2008). The economic vote: How political and economic institutions condition election results. Cambridge, U.K.: Cambridge University Press.

Ebeid, M., \& Rodden, J. (2006). Economic geography and economic voting: Evidence from the U.S. states. British Journal of Political Science, 36, 527-547.

Erikson, R. S., Mackuen, M. B., \& Stimson, J. A. (2002). The macro polity. New York: Cambridge University Press.

Fearon, J. D. (1999). Electoral accountability and the control of politicians. In A. Przeworski, S. C. Stokes \& B. Manin (Eds.), Democracy, accountability, and representation (pp. ix, 351 p.). New York: Cambridge University Press.

Fellowes, M. C., \& Wolf, P. J. (2004). Funding mechanisms and policy instruments: How business campaign contributions influence Congressional votes. Political Research Quarterly, 57, 315-324.

Ferejohn, J. (1999). Accountability and authority: Toward a theory of political accountability. In A. Przeworski, S. C. Stokes \& B. Manin (Eds.), Democracy, accountability, and representation. New York: Cambridge University Press.
Ferraz, C., \& Finan, F. (2008). Exposing corrupt politicians: The effects of Brazil's publicly released audits on electoral outcomes. Quarterly Journal of Economics, 123, 704-745.

Ferraz, C., \& Finan, F. (2011). Electoral accountability and corruption: Evidence from audits of local governments. American Economic Review, 101, 12741311.

Gailmard, S., \& Jenkins, J. A. (2009). Agency problems and electoral institutions: The Seventeenth Amendment and representation in the Senate. American Journal of Political Science, 53, 324-342.

Gasper, J. T., \& Reeves, A. (2011). Make it rain? Retrospection and the attentive electorate in the context of natural disasters. American Journal of Political Science, 55, 340-355.

Gelineau, F. (2007). Presidents, political context, and economic accountability: Evidence from Latin America. Political Research Quarterly, 60, 415-428.

Gerken, H. (2009). The democracy index: Why our election system is failing and how to fix it. Princeton: Princeton University Press.

Gilens, M. (2011). Affluence and influence: Economic inequality and political power in America. Princeton: Princeton University Press.

Godbout, J.-F., \& Belanger, E. (2007). Economic voting and political sophistication in the United States: A reassessment. Political Research Quarterly, 60, 541554.

Gomez, B. T., \& Wilson, J. M. (2006). Cognitive heterogeneity and economic voting: A comparative analysis of four democratic electorates. American Journal of Political Science, 50, 127-145.

Gomez, B. T., \& Wilson, J. M. (2007). Economic voting and political sophistication: Defending heterogeneous attribution. Political Research Quarterly, 60, 555-558.

Grant, R. W., \& Keohane, R. O. (2005). Accountability and abuses of power in world politics. American Political Science Review, 99, 29-44.

Grimmer, J. (2013). Appropriators not position-takers: The distorting effects of electoral incentives on Congressional representation. American Journal of Political Science, 57, 624-642.

Hardin, R. (2000). Democratic epistemology and accountability. Social Philosophy and Policy, 17, 110126.

Hellwig, T. (2012). Constructing accountability: Party position-taking and economic voting. Comparative Political Studies, 45, 91-118.

Hellwig, T., \& Samuels, D. (2008). Electoral accountability and the variety of democratic regimes. British Journal of Political Science, 38, 65-90.

Hobolt, S. B., \& Hoyland, B. (2011). Selection and sanctioning in European parliamentary elections. British Journal of Political Science, 41, 477-498. 
Holbrook, T. M., Clouse, C., \& Weinschenk, A. C. (2012). Bringing the president back in: The collapse of Lehmann Brothers and the evolution of retrospective voting in the 2008 presidential election. Political Research Quarterly, 65, 263-274.

Huber, G. A., \& Gordon, S. C. (2004). Accountability and coercion: Is justice blind when it runs for office? American Journal of Political Science, 48, 247-263.

Huber, G. A., Hill, S. J., \& Lenz, G. S. (2012). Sources of bias in retrospective decision-making: Experimental evidence on voters' limitations in controlling incumbents. American Political Science Review, 106, 720-741.

Hussey, W., \& Zaller, J. (2011). Who do parties represent? In P. K. Enns \& C. Wliezen (Eds.), Who gets represented? (pp. 247-284). New York: Russell Sage.

Jacobs, L. R., \& Shapiro, R. Y. (2000). Politicians don't pander: Political manipulation and the loss of democratic responsiveness. Chicago: University Press of Chicago.

Jones, D. R. (2010). Partisan polarization and Congressional accountability in House elections. American Journal of Political Science, 54, 323-337.

Jones, P. E. (2011). Accountability for policy positions and policy outcomes in Congress. Journal of Politics, 73, 764-782.

Kassow, B. J., \& Finocchiaro, C. J. (2011). Responsiveness and electoral accountability in the U.S. Senate. American Politics Research, 39, 1019-1044.

Kelly, J. M. (2003). Economic and political accountability in Fujimori's Peru. Journal of Politics, 65, 864880.

Kenney, C. D. (2003). Horizontal accountability: Concepts and conflicts. In S. Mainwaring \& C. Welna (Eds.), Democratic accountability in Latin America (pp. 55-76). Oxford: Oxford University Press.

Kunicova, J., \& Rose-Ackerman, S. (2005). Electoral rules and constitutional structures as constraints on corruption. British Journal of Political Science, 35, 573-606.

Lederman, D., Loayza, N. V., \& Soares, R. R. (2005). Accountability and corruption: Political institutions matter. Economics and Politics, 17, 1-35.

Lee, D. S., Moretti, E., \& Butler, M. J. (2004). Do voters affect or elect policies? Evidence from the U.S. House. Quarterly Journal of Economics, 119, 807859.

Lewis-Beck, M. S., \& Stegmaier, M. (2000). Economic determinants of electoral outcomes. Annual Review of Political Science, 3, 183-219.

Mainwaring, S. (2003). Introduction. In S. Mainwaring \& C. Welna (Eds.), Democratic accountability in Latin America (pp. 3-33). Oxford: Oxford University Press.

Maloy, J. S. (2008). The colonial American origins of modern democratic thought. New York: Cambridge University Press.
Maloy, J. S. (2011). The first Machiavellian moment in America. American Journal of Political Science, 55, 450-462.

Manin, B. (1997). The principles of representative government. New York: Cambridge University Press.

Manin, B., Przeworski, A., \& Stokes, S. C. (1999). Elections and representation. In A. Przeworski, S. C. Stokes \& B. Manin (Eds.), Democracy, accountability, and representation. New York: Cambridge University Press.

Maravall, J. M. (1999). Accountability and manipulation. In A. Przeworski, S. C. Stokes \& B. Manin (Eds.), Democracy, accountability, and representation (pp. 222-249). New York: Cambridge University Press.

Maravall, J. M. (2010). Accountability in coalition governments. Annual Review of Political Science, 13, 81-100.

Marsh, M., \& Tilley, J. (2010). The Attribution of Credit and Blame to Governments and Its Impact on Vote Choice. British Journal of Political Science, 40, 115134.

Mayhew, D. R. (1974). Congress: The electoral connection. New Haven: Yale University Press.

McCormick, J. P. (2011). Machiavellian democracy. New York: Cambridge University Press.

McDonald, M. D., Mendes, S. M., \& Budge, I. (2004). What are elections for? Conferring the median mandate. British Journal of Political Science, 34, 1-26.

Meinke, S. R. (2008). Institutional change and the electoral connection in the Senate: Revisiting the effects of direct election. Political Research Quarterly, 61, 445-457.

Moreno, E., Crisp, B. F., \& Shugart, M. S. (2003). The accountability deficit in Latin America. In S. Mainwaring \& C. Welna (Eds.), Democratic accountability in Latin America (pp. 79-131). Oxford: Oxford University Press.

Pande, R. (2011). Can informed voters enforce better governance? Experiments in low-income democracies. Annual Review of Economics, 3, 215-237.

Pereira, C., Melo, M. A., \& Figueiredo, C. M. (2009). The corruption-enhancing role of re-election incentives? Counter-intuitive evidence from Brazil's audit reports. Political Research Quarterly, 62, 731-744.

Powell, G. B. (2000). Elections as instruments of democracy: Majoritarian and proportional visions. New Haven: Yale University Press.

Powell, G. B. (2004). The chain of responsiveness. Journal of Democracy, 15, 91-105.

Powell, G. B., \& Whitten, G. D. (1993). A cross-national analysis of economic voting. American Journal of Political Science, 37, 391-414.

Rubenstein, J. (2007). Accountability in an unequal world. Journal of Politics, 69, 616-632.

Rudolph, T. J. (2003). Institutional context and the assignment of political responsibility. Journal of Politics, 65, 190-215. 
Samuels, D. (2004). Presidentialism and accountability for the economy in comparative perspective. American Political Science Review, 98, 425-436.

Schedler, A. (1999). Conceptualizing accountability. In A. Schedler, L. Diamond \& M. F. Plattner (Eds.), The self-restraining state: Power and accountability in new democracies. Boulder: L. Rienner.

Shapiro, I. (2005). The flight from reality in the human sciences. Princeton: Princeton University Press.

Singer, M. J. (2010). Who says it's the economy? Crossnational and cross-individual variation in the salience of economic performance. Comparative Political Studies, 44, 284-312.

Snyder, J. M., \& Stromberg, D. (2010). Press coverage and political accountability. Journal of Political Economy, 118, 355-408.

Stokes, S. C. (1999). What do policy switches tell us about democracy? In A. Przeworski, S. C. Stokes \&
B. Manin (Eds.), Democracy, accountability, and representation (pp. 98-130). New York: Cambridge University Press.

Tavits, M. (2007a). Clarity of reponsibility and corruption. American Journal of Political Science, 51, 218229.

Tavits, M. (2007b). Principle vs. pragmatism: Policy shifts and political competition. American Journal of Political Science, 51, 151-165.

Wlezien, C., \& Soroka, S. N. (2012). Political institutions and the opinion-policy link. West European Politics, 35, 1407-1432.

Zielinski, J., Slomczynski, K. M., \& Shabad, G. (2005). Electoral control in new democracies: The perverse incentives of fluid party systems. World Politics, 57, 365-395.

\section{About the Author}

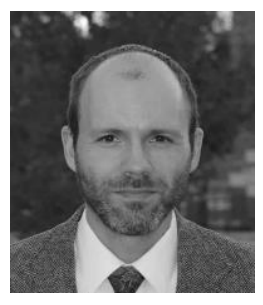

\section{Dr. J. S. Maloy}

J. S. Maloy is Associate Professor of Political Science at Oklahoma State University and (as of July 2014) co-editor (with Jeanette Mendez) of Political Research Quarterly. He is the author of two books on the history of democratic theory with Cambridge University Press, most recently Democratic Statecraft: Political Realism and Popular Power (2013). He has also published articles on a variety of topics related to the theoretical and empirical study of democracy in venues such as Journal of Politics, American Journal of Political Science, and Canadian Journal of Political Science. 